\title{
GURU KREATIF ANAK USIA DINI MELALUI PENDEKATAN TAKSONOMI BLOOM
}

\author{
Oleh \\ Ida Ayu Gde Wulandari', I Wayan Suyanta ${ }^{2}$ \\ 1,2Institut Hindu Dharma Negeri Denpasar \\ dayugdewulandari@gmail.com \\ suyanta.kaler@gmail.com
}

\begin{abstract}
The teacher is a model in learning. As a teacher, the teacher has the duty to develop all the potential possessed by students so that they can develop optimally. A creative teacher will produce creative students too. The same is true for a teacher who teaches students between 0 and 6 years. Students in this age range are the most appropriate age in developing all potential students. The potential developed in students includes cognitive, affective, and psychomotor domains in accordance with the development of psychology. With the teacher's understanding of the development of students which is the age of gold, it will give birth to a golden generation that brings progress to the country and nation. If a teacher is not creative in preparing and carrying out the learning process, it will not give birth to creative students. Being a creative teacher can be done through activities that support the development of students. Activities carried out by the teacher have goals to be achieved, both cognitive, affective, and psychomotor.
\end{abstract}

Keywords: teacher, creative, cognitive, affective, psycomotor

\begin{abstract}
ABSTRAK
Guru adalah model dalam pembelajaran. Guru bertugas untuk mengembangkan seluruh potensi yang dimiliki peserta didik sehingga dapat berkembang secara optimal. Seorang guru yang kreatif akan melahirkan peserta didik yang kreatif. Seorang pendidik anak usia dini adalah pendidik yang mengajarkan peserta didik antara 0 tahun sampai 6 tahun. Peserta didik dalam rentang usia tersebut adalah usia yang paling tepat dalam mengembangkan seluruh potensi peserta didik bahkan disebut sebagai golden age. Potensi yang dapat dikembangkan dalam diri peserta didik meliputi ranah kognitif, afektif, dan psikomotorik sesuai dengan perkembangan psikologi. Dengan pemahaman guru terhadap perkembangan peserta didik yang merupakan usia emas, maka akan melahirkan generasi emas yang membawa kemajuan bagi nusa dan bangsa. Begitu pula sebaliknya, apabila seorang guru tidak kreatif dalam mempersiapkan dan melaksanakan proses pembelajaran, maka tidak akan melahirkan peserta didik yang kreatif. Menjadi guru yang kreatif dapat dilakukan melalui kegiatan-kegiatan yang mendukung perkembangan peserta didik. Kegiatan yang dilakukan oleh guru memiliki tujuan yang ingin dicapai, baik kognitif, afektif, dan psikomotor.
\end{abstract}

Kata kunci : guru, kreatif, kognitif, afektif, psikomotor 


\section{PENDAHULUAN}

Menjadi seorang guru adalah pekerjaan profesional yang menuntut kreativitas. Keadaan. Situasi dan kondisi di kelas sangat dipengaruhi oleh faktor guru. Meskipun dewasa ini, orientasi pembelajaran sudah beralih dari teacher centered learning menjadi student centered learning, guru memegang peranan penting. Teacher centered learning atau pembelajaran berpusat pada guru adalah proses pembelajaran pembelajaran sepenuhnya dari guru sehingga peserta didik hanya menerima hal yang disampaikan kepada guru. Sedangkan student centered learning atau pembelajaran berpusat pada siswa adalah pembelajaran Pengelolaan kelas mulai dari persiapan, pelaksanaan, hingga evaluasi sepenuhnya guru memegang peranan penting. Seorang guru meskipun bertugas sebagai motivator dan fasilitator, namun guru memiliki kewenangan dalam memberikan petunjuk yang sekiranya dapat mrangsang perkembangan peserta didik.

Menurut Benjamin S. Bloom, dalam teorinya yang dijelaskan oleh Arikunto (2009:116) dikatakan bahwa tujuan belajar dirangkum dalam tiga ranah yang dikenal dengan sebutan taksonomi Bloom. Melalui taksonomi ini, banyak pakar pendidikan mengembangkan teori maupun praktek pembelajaran. Tiga kawasan yang dimaksud adalah (1) domain kognitif, yang berisi perilaku-perilaku yang menekankan aspek intelektual, tingkatannya adalah pengetahuan, pemahaman, aplikasi, analisis, sintesis, dan evaluasi; (2) domain afektif yang berisi perilaku-perilaku yang menekankan aspek perasaan dan emosi, tingkatannya adalah pengenalan, merespon, penghargaan, pengorganisasian, pengamalan dan; (3) domain psikomotor yang berisi perilaku-perilaku yang menekankan aspek keterampilan motorik, tingkatannya adalah peniruan, penggunaan, ketepatan, perangkaian dan naturalisasi.

Melalui terdapat tiga aspek perkembangan peserta didik. Ketiga aspek tersebut yaitu aspek kognitif, aspek afektif, dan aspek psikomotorik. Perkembangan peserta didik dapat berkembang secara optimal apabila guru mampu memahami tingkat perkembangan peserta didik. Tingkat perkembangan peserta didik berbeda sesuai dengan usia. Semakin bertambah usia, maka perlakuan guru akan berbeda terhadap peserta didik. Usia dini adalah rentang usia 0 tahun hingga 6 tahun.

Sebagai seorang guru, guru dituntut agar mampu mengoptimalkan perkembangan peserta didik. Guru memiliki kemampuan dalam mempersiapkan pembelajaran sesuai dengan tujuan yang hendak dicapai. Dalam pelaksanaan pembelajaran, guru mengetahui situasi dan kondisi di kelas. Oleh karena itu, guru berperan aktif dalam proses pembelajaran di kelas sehingga pembelajaran dapat berjalan efektif dan efisien serta dapat mencapai tujuan yang hendak dicapai. Efektif adalah pembelajaran yang berhasil guna dengan melibatkan seluruh sumber daya yang dimiliki sehingga dapat mencapai tujuan yang diharapkan. Efisien adalah pembelajaran yang berdaya guna.

Perkembangan peserta usia didik pada usia dini menuntut seorang guru agar lebih efektif menerapkan media pembelajaran sehingga mampu merangsang tumbuh kembang anak sehingga tujuan yang ingin dicapai dapat terwujud. Pertumbuhan dan perkembangan anak pada usia dini belum berkembang secara optimal. Sosok guru yang kreatif di dalam kelas diperlukan dalam pendidikan anak usia dini. Seorang guru yang kreatif adalah guru yang kreatif dalam merencanakan dan melaksanakan pembelajaran, kreatif dalam menciptakan media belajar, dan kreatif dalam mengevaluasi pembelajaran peserta didik. Menurut Munandar (1999:79), bahwa belajar kreatif tidak hanya menyangkut perkembangan kognitif (penalaran), tetapi juga berhubungan erat dengan penghayatan pengalaman belajar yang mengasyikkan. 


\section{PEMBAHASAN}

Masa usia dini merupakan periode emas (golden age) bagi perkembangan anak untuk memperoleh proses pendidikan. Periode ini adalah tahun-tahun berharga bagi seorang anak untuk mengenali berbagai macam fakta di lingkungannya sebagai stimulans terhadap perkembangan kepribadian, psikomotor, kognitif maupun sosialnya. Seorang guru yang kreatif akan mampu mendidik peserta didik sesuai dengan tujuan yang hendak dicapai. Tujuan yang hendak dicapai dalam disesuaikan dengan aspek yang akan dicapai. Berikut ini adalah kegiatan seorang guru yang dapat dilakukan ketika dalam merangsang tumbuh kembang anak usia dini, yaitu sebagai berikut.

\section{Aspek Kognitif}

Aspek kognitif adalah aspek pengetahuan yang harus dikembangkan kepada peserta didik usia dini. Pada usia dini, aspek kognitif tidak menekankan pada aspek penguasaan materi, tetapi terletak pada konsep pengenalan lingkungan. Aspek kognitif akan menambah pengetahuan anak yang nantinya akan mendorong rasa ingin tahu (curiosity). Anak usia dini dapat dikenalkan dengan hal-hal yang ada di lingkungan sekitar. Pengenalan lingkungan sekitar kepada anakanak akan memudahkan peserta didik untuk tumbuh secara optimal karena peserta didik merasa dekat dengan lingkungannya. Anak akan lebih mudah berimajinasi karena salah satu sifat anak adalah senang berberimajinasi terhadap hal-hal baru. Kegiatan-kegiatan yang dapat mendukung perkembangan aspek kognitif dapat dimulai dari pengelompokan, membedakan, dan menyebutkan.

Berikut ini adalah kegiatan-kegiatan yang mendukung perkembangan anak usia dini, yaitu sebagai berikut.

a) Mengelompokkan benda yang sama dan sejenis

b) Menyebutkan 4 bentuk (lingkaran, bujur sangkar, segitiga, segi panjang)

c) Membedakan besar-kecil, panjangpendek (dua dimensi)

d) Membedakan rasa

e) Membedakan bau f) Menyebutkan bilangan 1-10 tanpa mengenal konsep

g) Pengelompokan warna (lebih 5 warna) dan menyebut warna

Berdasarkan kegiatan-kegiatan tersebut di atas, maka diharapkan dapat meranstimulasi perkembangan peserta peserta didik dalam aspek kognitif.

\section{Aspek Afektif}

Dalam Undang-Undang No. 20 Tahun 2003 Pasal 3 dijelaskan bahwa Pendidikan Nasional berfungsi mengembangkan kemampuan dan membentuk watak serta peradaban bangsa yang bermartabat dalam rangka mencerdaskan kehidupan bangsa, bertujuan untuk berkembangnya potensi peserta didik, agar menjadi manusia yang beriman dan bertakwa kepada Tuhan Yang Maha Esa, berakhlak mulia, sehat, berilmu, cakap, kreatif, mandiri, dan menjadi warga negara yang demokratis.

Suatu pembelajaran dapat terwujud sesuai dengan amanat undang-undang apabila dalam pembelajaran berhubungan dengan pembentukan sikap dan nilai. Hakikat dari pendidikan dalam ranah afektif adalah pendidikan nilai. Menurt Wina (2009:274), pendidikan nilai pada dasarnya proses penanaman nilai kepada peserta didik yang diharapkan oleh karenanya siswa dapat berperilaku sesuai dengan pandangan yang dianggapnya baik dan tidak bertentangan dengan norma-norma yang berlaku.

Perkembangan afektif anak usia dini dapat dilatih melalui kegiatan berikut dengan mengenal aspek sosial emosional yang dapat menunjang perkembangan afektifnya, yaitu sebagai berikut.

a) Mengenal etiket makan jadwal teratur

b) Terbiasa dengan berbagi

c) Tidak menangis jika berpisah dengan orang tua

d) Menunjukkan ekspresi wajar jika marah, sedih, takut, dan sebagainya

e) Menjadi pendengar dan pembicara yang baik

f) Membereskan mainan setelah selesai bermain 
g) Sabar menunggu giliran dan terbiasa antri

h) Mengenal peraturan dan mengikuti peraturan

i) Mengerti akibat jika melakukan kesalahan/melanggar aturan

j) Memiliki kebiasaan teratur

Berdasarkan kegiatan - kegiatan tersebut, diharapkan mampu menstimulasi perkembangan anak dalam ranah afektif.

\section{Aspek Psikomotor}

Pada usia pra sekolah, anak-anak kebutuhan utamanya adalah bermain karena dapat melatih motorik mereka untuk bisa berkembang (Elfindri, dkk, 2012:111). Aspek psikomotor anak usia dini dapat dilatih melalui beberapa kegiatan di bawah ini yang dapat merangsang pertumbuhan dan perkembangannya menjadi lebih optimal, yaitu sebagai berikut.

a) Berjalan dengan stabil (keseimbangan tubuh semakin baik)

b) Naik turun tangga tanpa berpegangan

c) Memanjat

d) Berlari dengan stabil atau berlari di tempat

e) Menendang, menangkap dan melempar bola dengan jarak jauh

f) Melompat dengan satu kaki bergantian

g) Merayap dan merangkak lurus ke depan

h) Berjingkat (berjalan bertumpu pada ujung jari kaki)

i) Menuang (air, biji-bijian) tanpa tumpah

j) Memegang benda kecil dengan telunjuk jari

k) Melipat kertas mengikuti garis

1) Membuat garis lurus, vertikal, melengkung

Berdasarkan kegiatan-kegiatan

tersebut, diharapkan mampu menstimulasi perkembangan anak dalam ranah psikomotor.

\section{PENUTUP}

Berdasarkan pemaparan yang telah dijelaskan maka dapat disimpulkan bahwa sosok guru yang kreatif mampu mengembangkan aspek kognitif, aspek afektif, dan aspek psikomotor melalui kegiatan-kegiatan yang dipersiapkan oleh guru. Peran guru dalam pendidikan anak usia dini memiliki peran penting dalam perkembangan selanjutnynya. Oleh karena itu, seorang guru pada anak usia dini hendaknya guru yang kreatif yang dapat merangsang pertumbuhan dan perkembangan peserta didik secara optimal.

\section{DAFTAR PUSTAKA}

Arikunto, Suharsimi. 2009. Dasar-dasar Evaluasi Pendidikan. Jakarta: Bumi Aksara

Elfindri, dkk (Editor: Indrayani). Pendidikan Karakter Kerangka, Metode dan Aplikasi untuk Pendidik dan Profesional. Jakarta: Baduose Media Jakarta

Unandar, S.C. Utami. 1999. Mengembangkan Bakat dan Kreativitas Anak Sekolah Penuntun bagi Guru dan Orang Tua. Jakarta: PT Grasindo

Sanjaya, Wina. 2009. Strategi Pembelajaran Berorientasi Standar Proses Pendidikan. Jakarta: 2009

UU No. 20 Tahun 2003 Tentang Sistem Pendidikan Nasional 